\title{
Fruit pastes with organic honey texturized with gellan gum: bioacessibility of antioxidant activity and sensory analysis fruit pastes with gellan and organic honey
}

\author{
Eveline de Alencar COSTA ${ }^{1}$, Paulo Henrique Machado de SOUSA ${ }^{1,2 *}$ (D), Adriana Camurça Pontes SIQUEIRA ${ }^{1}$, \\ Evânia Altina Teixeira de FIGUEIREDO ${ }^{2}$, Sandro Thomaz GOUVEIA², Raimundo Wilane de FIGUEIREDO ${ }^{2}$, \\ Carla Soraya Costa MAIA ${ }^{3}$, Deysilene Soares GOMES 2
}

\begin{abstract}
Three paste formulations were developed for four fruits: caja, murici with mango and pitanga, with differentiated percentages of fruit pulp, organic honey and gellan gum. Pulps, honey and fruit paste formulations were analyzed by antioxidant capacity, vitamin $\mathrm{C}$ and in vitro bioaccessibility. All formulations showed a high content of vitamin $\mathrm{C}$, antioxidant action and the bioaccessibility. All the formulations were accepted regarding the overall impression, except MM3 (murici pulp:mango pulp:honey 50:50:00 and 0.25\% gellan gum) and PI1 (pitanga pulp: honey 90:10 and 0.6\% gellan gum). Therefore, fruit pastes are options to encourage consumption of tropical fruits of agro-biodiversity in the Brazilian Northeast.
\end{abstract}

Keywords: structured fruit; antioxidant activity; sensory acceptance; microbiological stability; bioaccessibility.

Practical Application: This study deals with the development of hydrocolloid-based products and fruits of agro-biodiversity in the Brazilian Northeast, the sensory acceptance by CATA and the hedonic scale method in order to evaluate possible fruit paste formulations.

\section{Introduction}

Fruit pastes are new structured products based on fruit or vegetables and hydrocolloids. These are used to obtain acceptable texture by consumers, for example, agar, carrageenan, alginate, gellan, xanthan, gelatin and other mixtures often applied in developing food gels. Fruit pastes are considered ready-to-use products, but the nutritional properties of the fruit are maintained and are accepted from a sensory point of view. One of the most used hydrocolloids is gellan gum because their gels are characterized by excellent flavor release, rapid formation of the gel and use at low concentrations (Banerjee et al., 2013). On the other hand, gellan gum is influenced by factors that involve the gel formation such as temperature, $\mathrm{pH}$, sugar concentration and the presence of metal ions. These aspects will vary depending on the type of gellan gum. High acyl gellan gum are those that undergo precipitation with alcohol (natively) shortly after your production. Low acyl gellan is exposed to alkali at high temperature, the acyl groups are hydrolysed and deacylated (Dickinson, 2009; Lersch, 2014; Phillips \& Williams, 2009).

High acyl gellan forms gels at high temperatures between $70^{\circ} \mathrm{C}$ and $80^{\circ} \mathrm{C}$, being thermoreversible, meaning that it dissolves when subjected to prolonged heating, and gel-sol transition occurs. However, the formed gel is soft, elastic, opaque and gives high viscosity solutions; unlike low acyl, which form gels in temperature near $60^{\circ} \mathrm{C}$ (although it may happen between $10^{\circ} \mathrm{C}$ and $60^{\circ} \mathrm{C}$ ), providing firmer texture, brittleness, transparency and stable temperature (Lersch, 2014; Li \& Nie, 2015; Phillips
\& Williams, 2009). Because some biodiverse fruits of northeast Brazil are little known and exploited, we aimed to develop fruit pastes in three flavors (caja, pitanga, murici with mango), as well as to perform antioxidant activity and vitamin $\mathrm{C}$ content in order to quantify the in vitro bioaccessibility of these last two and find their microbiological stability and sensory evaluation. The mango was added to the murici to lower its acidity and taste.

The pasts have been prepared with the objective of being the basic ingredients for other preparations (for example, as cake toppings and fillings) to contribute to the utilization of these plants/fruit outside the harvest period and create alternatives for a long time when compared to fresh fruit.

\section{Materials and methods}

\subsection{Materials}

Frozen fruit pulps were acquired from retail commerce, including murici, mango pulp and caja from supermarkets in the city of Fortaleza, and pitanga obtained from a market in the city of Juazeiro do Norte-CE.

The hydrocolloid used was low acyl gellan (gellan gum, Sosa batch $161014^{\circledR}$ ).

The honey used (Necta ${ }^{\circledR}$ Floral, Phloem) was acquired from a market in the city of Fortaleza of organic production, along with a certificate of purity and Federal Inspection Stamp (SIF). 


\subsection{Fruit formulations}

The produced products were named pastes. All three were previously selected formulations from sensory analysis previews in a laboratory (focus group product evaluation with more than 12 tasters and without necessarily consensus among them when questioned about overall impression, taste, texture, aroma and color), being chosen as those with better acceptance and with suitable characteristics for fruit pastes.

The percentages of frozen fruit pulp, gellan and honey used in the formulations are shown in Table 1. The combinations of the three ingredients were performed randomly and were selected for the study for being the most accepted in a previous sensory analysis.

For the product preparation, the pulp was mixed with the honey and the gellan. This mixture was heated to approximately $88 \pm 2{ }^{\circ} \mathrm{C}$ for $30 \mathrm{sec}$ in a SPM-018 Yammi $^{\circledR}$ Thermomix food processor until complete dissolution of low acyl gellan (Danalache et al., 2015a). The obtained mixture was poured into plastic cups and then cooled to room temperature for 30 minutes. The glasses were subsequently sealed and stored at refrigeration temperature of $5{ }^{\circ} \mathrm{C}$ for 12 hours to complete the jellification process. The process was carried out in three repetitions.

Good practices were followed during handling of the formulations and samples were subjected to shelf-life tests within 32 days and sensory analysis (as described below).

\subsection{Determinations}

The fruit pulp, organic honey and developed fruit pastes were analyzed for the antioxidant capacity, the vitamin $\mathrm{C}$ and simulated gastrointestinal digestion in vitro. All trials were conducted three times.

Vitamin C was determined by the titrimetric method of Tillmans according to Association of Official Analytical Chemists (2005).

Total antioxidant activity was determined by the radical ABTS method described by Re et al. (1999) adapted by Rufino et al. (2010), where they made use of a standard calibration Trolox curve of, with the results expressed in $\mu \mathrm{M} /$ sample Trolox.

\subsection{In vitro gastrointestinal digestion simulation}

The in vitro gastrointestinal simulation measured only antioxidant activity and vitamin $\mathrm{C}$ present in the fruit pulp and the honey used in formulations and fruit pastes.

The methodology proposed by Miller et al. (1981) with adaptations of Moura \& Canniatti-Brazaca (2006) was implemented in simulating the digestion steps, using enzymes to evaluate the bioaccessibility of antioxidant compounds and vitamin $\mathrm{C}$ in fruit pulp, organic honey and in directories. The sample $(20 \mathrm{~mL})$ was initially submitted to the pepsin solution $(16 \mathrm{~g} / 100 \mathrm{~mL}$ of $\mathrm{HCl} 0.1 \mathrm{~mol} \mathrm{~L}-1$ ) in a constant temperature bath at $37^{\circ} \mathrm{C}$ with agitation for 2 hours, simulating gastric digestion. Then the sample was submitted to a solution of pancreatin and bile salts ( $0.5 \mathrm{~g}$ of pancreatin and $3.13 \mathrm{~g}$ bile extract in $125 \mathrm{~mL}$ of $\mathrm{NaHCO} 3$ $0.1 \mathrm{~mol} \mathrm{~L}-1)$, by adjusting the $\mathrm{pH}$ to $0.5 \mathrm{~mol} \mathrm{~L}-1$ of $\mathrm{NaOH}$ up to $7.5 \mathrm{pH}$ ( $\mathrm{pH}$ found in the human intestine) and placing them on dialysis membranes, kept in water bath at $37^{\circ} \mathrm{C} / 2$ hours. Analytical procedures were carried out in triplicate. The bioaccessibility percentage was calculated according to Briones-Labarca et al. (2011), expressed in percentage, using the Equation 1:

Bioaccessibility $\%=100 \times(D / E)$

where: $\mathrm{D}$ is the content of the dialysate fraction; and $\mathrm{E}$ is the total compound (antioxidant activity and vitamin C) content of the sample (data corresponding to each determination). Physical and chemical analysis were submitted to Tukey test (5\% of significance).

\subsection{Microbiological tests}

The analyses were conducted according to methodology recommended by American Public Health Association (2001) and Silva et al. (2010) for the following: psychrotrophic aerobic microorganisms; coliforms at $35^{\circ} \mathrm{C}$ and $45^{\circ} \mathrm{C}$; molds and yeasts; and Salmonella spp.

\subsection{Sensory tests}

The following sensory tests were performed: acceptance by hedonic scale of nine points ranging from 1 (disliked very much) to 9 (liked very much) (Stone \& Sidel, 2004) for the attributes color, appearance, aroma, texture (softness) and overall impression. The attainment of sensory studies was approved by the Research Ethics Committee (CEP) via the opinion $n^{\circ} 1.829 .642$, and a written consent was signed by all participants. All panellists and participants were 100 not trained volunteers, over 18 years of age. The samples were served at $7 \pm 2{ }^{\circ} \mathrm{C}$ in individual servings coded with three-digit numbers. The samples were presented using a balanced complete randomized block. The hedonic scale results were submitted to Tukey test (5\%).

More than 33 attributes specific to each formulation were established for the Check-all-That-Apply (CATA) test (Plaehn, 2012) (Table A1), and the results were expressed through Principal Components Analysis (PCA) (Appendix A).

Table 1. Fruit paste formulations.

\begin{tabular}{|c|c|c|c|c|c|c|c|c|c|}
\hline \multirow{3}{*}{ Employed ingredients } & \multicolumn{9}{|c|}{ Formulations (\%) } \\
\hline & \multicolumn{3}{|c|}{ Caja paste } & \multicolumn{3}{|c|}{ Pitanga paste } & \multicolumn{3}{|c|}{ Murici with mango paste } \\
\hline & $\mathrm{C} 1$ & $\mathrm{C} 2$ & $\mathrm{C} 3$ & PI1 & PI2 & PI3 & MM1 & MM2 & MM3 \\
\hline Fresh fruit pulp: honey & $90: 10$ & $86: 14$ & $86: 14$ & $90: 10$ & $86: 14$ & $86: 14$ & $45: 45: 10$ & $45: 45: 10$ & $50: 50: 0$ \\
\hline
\end{tabular}


Tukey test and PCA were performed using the software program XLSTAT (2017) (Addinsoft, New York, USA), version 2017.2.

\section{Results and discussion}

\subsection{Antioxidant activity, vitamin $C$ and in vitro bioaccessibility}

Fruit pastes showed mean low antioxidant activity when compared with the fruit pulp, except for the formulations of caja which had similar values (Table 2 ).

Comparing with our results, Carvalho et al. (2015) found that vitamin $\mathrm{C}$ content in the caja (Spondias mombin L.) was higher $(13.7 \pm 0,16 \mathrm{mg} / 100 \mathrm{~g})$, while antioxidant activity value was lower $(2.45 \pm 0.07 \mu \mathrm{mol} /$ Trolox $)$. Souza et al. (2012) obtain high antioxidant activity and vitamin $\mathrm{C}$ in murici (Byrsonima crassifolia L. Rich: $57.25 \pm 4.05 \mu \mathrm{mol} /$ Trolox and $47.44 \pm 3.26 \mathrm{mg} / 100 \mathrm{~g}$, respectively). It is noted that the average for vitamin $\mathrm{C}$ in all fruit pastes was higher than in the frozen fruit pulps, and therefore might be associated with the percentage of honey used in formulations, since this contains vitamin $\mathrm{C}$ in its composition (Table 1). This result deduces that this vitamin present in the organic honey was stable during the paste processing. Costa et al. (2017) found vitamin C content in structured murici (made with high acyl gellan gum with percentages of $0.25 \%$ to $1.0 \%$ ) between $15.24 \mathrm{mg} / 100 \mathrm{~g}$ and $19.81 \mathrm{mg} / 100 \mathrm{~g}$, below the averages obtained for fruit pastes.

Regarding the in vitro bioaccessibility assay, antioxidant activity in fruits showed average retention above $36 \%$ in pitanga, as well as $20 \%$ in caja and murici with mango pastes, respectively (Table 2).

For the in vitro vitamin $\mathrm{C}$ retention, the average percentage was higher in pitanga than in caja and murici with mango. However, this vitamin presented the greatest in vitro bioaccessibility $\%$ in pitanga-PI3.

Nevertheless, Martins et al. (2016) point out that the compounds that promote antioxidant activity are highly useful in the control of free radicals produced by the cells, i.e. direct elimination of reactive oxygen species (ROS) (such as radical hydroxyl radical, superoxide, hydrogen peroxide, peroxide radical, Singlet oxygen, and hydroperoxide), avoiding undesirable effects and supporting the body in detoxification effects.

Globally, fruit pastes are new choices of food with vitamin C, antioxidant activity; with average in vitro retention percentages of $15 \%$ and $22 \%$ (Table 2), respectively, and are therefore healthy options to the human organism, especially against free radicals.

\subsection{Sensory acceptance of fruit paste}

The recruited panellists were men (44\%) and women (66\%) aged between 18 and 54 years old.

The averages of the attributes (appearance, color, aroma, texture, taste and overall impression), evaluating the product formulations of caja pulp ranged from 6.0 to 7.0, matching the scores "I slightly liked" and "I moderately liked", respectively, but there was no significant difference between them $(\mathrm{p} \leq 0.05)$. Sensory averages of murici with mango for the attributes varied between 5.0 ("not liked nor disliked") to 7.0 ("I moderately liked"). Pitanga paste had averages for all attributes ranging from 4.0 ("slightly disliked") and 6.5 ("slightly liked"). However, the formulations of the pastes murici and mango-MM3 and pitanga-PI1 differed significantly $(\mathrm{p} \leq 0.05)$ between the others for the appearance attributes, color, texture, taste and overall impression (Table 3, Table A2).

The appearance attribute provided larger averages (up to 6, regarding the term "slightly liked") in all the formulations of caja,

Table 2. Antioxidant activity and vitamin $\mathrm{C}$ of the samples before (Native) and after the in vitro digestion and their bbioaccessibility percentage.

\begin{tabular}{|c|c|c|c|c|c|c|c|}
\hline \multirow[b]{2}{*}{ Sample } & \multirow[b]{2}{*}{ Formulation } & \multicolumn{3}{|c|}{ Antioxidant Activity ( $\mu \mathrm{M} /$ Trolox) } & \multicolumn{3}{|c|}{ Vitamin C (mg/100 g) } \\
\hline & & Native & $\begin{array}{c}\text { in vitro } \\
\text { digestion }\end{array}$ & $\begin{array}{c}\% \\
\text { Bioaccessibility }\end{array}$ & Native & $\begin{array}{c}\text { in vitro } \\
\text { Digestion }\end{array}$ & $\begin{array}{c}\% \\
\text { bioaccessibility }\end{array}$ \\
\hline Caja pulp & - & $9.56 \pm 0.18$ & $1.90 \pm 0.20$ & 19.87 & $8.93 \pm 0.04$ & $8.78 \pm 0.99$ & 98.32 \\
\hline Murici pulp & - & $29.36 \pm 0.84$ & $2.92 \pm 0.21$ & 9.94 & $6.61 \pm 1.04$ & $7.05 \pm 1.11$ & 106.65 \\
\hline Mango pulp & - & $2.92 \pm 0.07$ & $2.22 \pm 0.19$ & 76.02 & $28.98 \pm 0.89$ & $8.33 \pm 1.11$ & 28.74 \\
\hline Pitanga pulp & - & $5.80 \pm 0.16$ & $2.07 \pm 0.12$ & 35.68 & $5.10 \pm 0.09$ & $7.82 \pm 1.04$ & 153.33 \\
\hline Organic honey & - & $5.70 \pm 0.17$ & $1.15 \pm 0.02$ & 20.17 & $7.77 \pm 1.03$ & $3.57 \pm 0.01$ & 46.94 \\
\hline \multirow[t]{3}{*}{ Caja paste } & $\mathrm{C} 1$ & $10.02 \pm 1.20$ & $2.14 \pm 0.36$ & 21.35 & $38.70 \pm 5.16$ & $5.86 \pm 0.00$ & 15.14 \\
\hline & $\mathrm{C} 2$ & $8.61 \pm 0.95$ & $2.12 \pm 0.50$ & 24.62 & $22.33 \pm 0.00$ & $4.56 \pm 1.13$ & 20.42 \\
\hline & $\mathrm{C} 3$ & $10.33 \pm 0.06$ & $2.17 \pm 0.39$ & 21.00 & $13.89 \pm 1.72$ & $6.46 \pm 2.90$ & 46.51 \\
\hline Murici with & MM1 & $9.06 \pm 0.21$ & $2.45 \pm 0.38$ & 27.04 & $68.46 \pm 5.16$ & $6.51 \pm 1.13$ & 9.51 \\
\hline \multirow[t]{2}{*}{ mango paste } & MM2 & $11.79 \pm 0.48$ & $2.32 \pm 0.17$ & 19.67 & $32.74 \pm 2.58$ & $5.21 \pm 1.13$ & 15.91 \\
\hline & MM3 & $9.93 \pm 0.81$ & $2.17 \pm 0.19$ & 21.85 & $24.81 \pm 1,72$ & $5.21 \pm 1.13$ & 21.00 \\
\hline \multirow[t]{3}{*}{ Pitanga paste } & PI1 & $7.74 \pm 1.40$ & $2.81 \pm 0.14$ & 36.30 & $32.74 \pm 5.16$ & $8.46 \pm 2.26$ & 25.85 \\
\hline & $\mathrm{PI} 2$ & $3.34 \pm 0.16$ & $1.60 \pm 0.14$ & 48.00 & $16.37 \pm 2.58$ & $7.81 \pm 0.00$ & 47.70 \\
\hline & $\mathrm{PI} 3$ & $3.78 \pm 0.22$ & $2.44 \pm 0.33$ & 64.55 & $10.91 \pm 1.72$ & $8.46 \pm 1.13$ & 77.54 \\
\hline
\end{tabular}

C1 = caja pulp:honey 90:10 and Gellan gum 0.6\%; C2 = caja pulp:honey 86:14 and Gellan gum 0.6\%; C3 = caja pulp:honey 86:14 and Gellan gum 0.7\%; MM1 = murici pulp:mango pulp:honey 45:45:10 and Gellan gum 0.1\%; MM2 = murici pulp:mango pulp:honey 45:45:10 and Gellan gum 0.2\%; MM3 = murici pulp:mango pulp:honey 50:50:00 and Gellan gum 0.25\%; PI1 = pitanga pulp:honey 90:10 and Gellan gum 0.6\%; PI2 = pitanga pulp:honey 86:14 and Gellan gum 0.6\%; PI3 = pitanga pulp:honey 86:14 and Gellan gum 0.75\%. Results expressed as mean ( \pm standard deviation), except the in vitro bioaccessibility; $(\mathrm{n}=3)$. 
Table 3. Result of sensory acceptance of the fruit paste formulations.

\begin{tabular}{|c|c|c|c|c|c|c|c|c|c|}
\hline \multirow{2}{*}{ Sensory attributes } & \multicolumn{3}{|c|}{ Caja paste } & \multicolumn{3}{|c|}{ Murici with mango paste } & \multicolumn{3}{|c|}{ Pitanga paste } \\
\hline & $\mathrm{C} 1$ & $\mathrm{C} 2$ & $\mathrm{C} 3$ & MM1 & MM2 & MM3 & PI1 & PI2 & $\mathrm{PI} 3$ \\
\hline Appearance & $6.42 \mathrm{a}$ & $6.67 \mathrm{a}$ & $6.16 \mathrm{a}$ & $6.50 \mathrm{a}$ & $6.20 \mathrm{a}$ & $5.30 \mathrm{~b}$ & $4.71 \mathrm{~b}$ & $6.33 \mathrm{a}$ & $5.96 \mathrm{a}$ \\
\hline Color & $7.16 \mathrm{a}$ & $7.03 \mathrm{a}$ & $7.04 \mathrm{a}$ & $7.02 \mathrm{a}$ & $6.72 \mathrm{a}$ & $6.13 \mathrm{~b}$ & $5.27 \mathrm{~b}$ & $6.55 \mathrm{a}$ & $6.35 \mathrm{a}$ \\
\hline Aroma & $7.00 \mathrm{a}$ & $6.54 \mathrm{a}$ & $7.04 \mathrm{a}$ & $5.73 \mathrm{a}$ & $5.54 \mathrm{a}$ & $5.51 \mathrm{a}$ & $5.70 \mathrm{a}$ & $6.09 \mathrm{a}$ & $5.93 \mathrm{a}$ \\
\hline Texture & $6.23 \mathrm{a}$ & $6.41 \mathrm{a}$ & $5.83 \mathrm{a}$ & $6.25 \mathrm{a}$ & $5.75 \mathrm{a}$ & $5.07 \mathrm{~b}$ & $4.37 \mathrm{~b}$ & $6.29 \mathrm{a}$ & $5.94 \mathrm{a}$ \\
\hline Flavor / Taste & $6.56 \mathrm{a}$ & $6.48 \mathrm{a}$ & $5.97 \mathrm{a}$ & $6.12 \mathrm{a}$ & $5.75 \mathrm{a}$ & $4.66 \mathrm{~b}$ & $4.06 \mathrm{~b}$ & $5.35 \mathrm{a}$ & $5.64 \mathrm{a}$ \\
\hline Overall impression & $6.53 \mathrm{a}$ & $6.32 \mathrm{a}$ & $5.97 \mathrm{a}$ & $6.10 \mathrm{a}$ & $5.72 \mathrm{a}$ & $4.96 \mathrm{~b}$ & $4.38 \mathrm{~b}$ & $5.61 \mathrm{a}$ & $5.60 \mathrm{a}$ \\
\hline
\end{tabular}

$\mathrm{C} 1$ = caja pulp:honey 90:10 and Gellan gum 0.6\%; C2 = caja pulp:honey 86:14 and Gellan gum 0.6\%; C3 = caja pulp:honey 86:14 and Gellan gum 0.7\%; MM1 = murici pulp:mango pulp:honey 45:45:10 and Gellan gum 0.1\%; MM2 = murici pulp:mango pulp:honey 45:45:10 and Gellan gum 0.2\%; MM3 = murici pulp:mango pulp:honey 50:50:00 and Gellan gum $0.25 \%$; PI1 = pitanga pulp:honey 90:10 and Gellan gum 0.6\%; PI2 = pitanga pulp:honey 86:14 and Gellan gum 0.6\%; PI3 = pitanga pulp:honey 86:14 and Gellan gum 0.75\% Means with the same letters on the same line between the formulations did not differ among themselves at the significance level of $5 \%$ for the Tukey test.

MM1, MM2, PI2 and PI3. This assessment can be justified by the fact that the product is new, becoming "undefined" by the consumer. Regarding color, all caja and sample formulations MM1 presented an average above 7, indicating that the panellists moderately liked the color. Both products feature a yellow color, which seems to have important influence to the sensory acceptance. According to Dutcosky (2013), color is one of the first characteristics analyzed by the individual, being closely linked to appearance and linked to personal reactions of acceptance, indifference or rejection.

With regard to the aroma, caja formulations presented an average between 6 and 7, where the panellists cited they slightly and moderately liked them, in that order. However, all murici with mango formulations scored an average of 5 for the aroma, i.e., they didn't like or dislike it. This result indicates that the mango may have reduced the specific smell of murici. However, the sample PI2 presented the top average for the scent between the formulations of pitanga.

The textures of structured fruit were accepted in the following descending order: C2, PI2, MM1 and C1, because they received acceptance with average results equal to 6 . Therefore, it appears that the low percentage of gellan gum employed in all these formulations: C1, C2 and PI2 (0.6\%) and MM1 (0.1\%) provided acceptable texture to the product type.

Danalache et al. (2015a) analyzed mango bars solid texture with different concentrations of gellan gum (high and low acyl) and found that low concentrations of gellan $(0.75 \%$ high acyl and $0.25 \%$ low acyl) provided the desired texture, corroborating with the present study. In another study, Danalache et al. (2015b) verified the rheological characteristics of mangos, the kinetics of forming gels, and concluded that the high percentage of gellan gum (high acyl) and sucrose tends to compromise the quality of the gel, weakening it.

The flavor attribute revealed less acceptance in two samples: MM3 and PI1 with 4.66 and 4.06 averages. Therefore, it is observed that the percentage of honey employed in these formulations directly influenced flavor, because the sample did not have the presence of the MM3 honey, and only 10\% PI1, being the lowest percentage used in the pitanga paste product. These two formulations presented average overall impression even lower than the other samples, revealing that the flavor attribute can influence this assessment.
Caja pulp formulations provided overall impression results indicative of acceptance, without significant difference $(\mathrm{p} \leq 0.05)$. The MM1 formulation was also accepted in relation to the overall impression.

On the other hand, the overall impression of the samples MM2, PI2 and PI3, obtained results referring to the item indifferent, where the tasters neither liked nor disliked them.

\subsection{CATA test analysis}

It was found that 18 of the cited the terms differed statistically among the sample of pitanga (Figure A1) and 16 between the formulations of the murici with mango.

The formulations from the caja were very similar because only six terms showed a significant difference between samples (homogeneous, light yellow color, presence of liquid, soft, sandy and sour taste) (Table A2). This result confirms with the data obtained in the hedonic test (Table 3), as the caja samples did not differ statistically between the examined attributes. A sour taste is fairly typical of this fruit, which presents total titratable acidity ranging from 1.0 to $1.6 \%$ citric acid and $\mathrm{pH}$ between 2.49 to 2.9, i.e. properties that confer such taste (Canuto et al., 2010; Carvalho et al., 2015; Gadelha et al., 2009). This high acidity is responsible for influencing the structure of the gel, thus promoting syneresis (Danalache et al., 2015b).

Among the terms that showed a significant difference between the samples of murici-mango most often were: Brightness, golden yellow, firm, gelatinous, sandy, acid taste, fruit taste, murici taste and strange texture. Thus, by CATA test, are the terms that characterize the formulations of murici-manga. The sour taste of the murici with mango may be related to the low content of honey used in the formulations; the flavor had greater evidence of murici than the mango flavor, even though they were employed in the same amount. This can be justified by the unique flavor of the murici. The term "sandy" is given by the typical characteristic of "mass/massent" and brittle texture of this fruit (Araujo et al., 2009). It can also be associated with the strange texture.

The characteristics that showed higher averages of significant frequencies in three pitanga pastes were brightness, presence of liquid, soft, astringent, fruity aroma, acid aroma, sweet aroma, honey aroma, pitanga aroma, acid taste, bitter taste and 
pitanga flavor. Pitanga pastes may present higher syneresis due to the moister content, above $88 \%$ (Universidade Estadual de Campinas, 2011).

Bagetti et al. (2011) also identified high percentage of humidity in purple, red and yellow pitangas $(81.2 \% ; 83.9 \%$ and $84.7 \%)$. The bitter taste and astringency is a characteristic of the species, which may be related to the high content of phenolic substances responsible for conferring bitter taste and astringency (Maia et al., 2009; Rocha et al., 2013).

For Ares et al. (2014) and Dooley et al. (2010), the test is a qualitative analysis employed to identify whether the attributes presented to the judge are suitable to describe the product. On the other hand, it does not allow quantifying the intensity of presence or absence of the terms. Castura et al. (2016) point out that this kind of analysis presents advantages over the sensory descriptive tests with trained tasters because they are faster and less expensive. The authors cite the CATA can indicate similarities between products, but the selected attributes tend to categorize and differentiate the samples, presenting significant differences between them.

\subsection{Principal Component Analysis (PCA) for testing CATA}

The mentioned characteristics for caja that most correlated with the formulation $\mathrm{C} 1$ were sweet taste, homogeneous and light yellow color. The C2 sample presented five more represented features: sandy, sour taste, yellow color darkened, presence of liquid and strange texture. Also, only one attribute was mapped for C3 ("mushy"), but in distant position when assessing the chart (Figure 1).

The attributes that were most related with MM1 (murici pulp:mango pulp:honey 45:45:10 and gellan gum $0.1 \%$ ): gelatinous, firm, appearance of jelly, mango taste and jelly texture. The formulation MM2 (murici pulp:mango pulp:honey 45:45:10 and gellan gum 0.2\%) was correlated as sweet aroma, succulent, brightness and sweet taste; and the MM3 (murici pulp:mango pulp:honey 50:50:00 and gellan gum 0.25\%): strange flavor, strange texture, bitter taste, acid taste and acidic aroma.

In the formulation of pitanga PI1 (pitanga pulp:honey 90:10 and Gellan gum $0.6 \%$ ) the presence of liquid, strange texture, dark red color, acid aroma, soft, bitter taste, acid taste and opaque color were cited. For formulation PI2 (PI2: pitanga pulp:honey $86: 14$ and Gellan gum $0.6 \%$ ): jelly appearance, bright red color, gelatinous, jelly texture, homogeneous and mushy. The brightness feature was cited for both PI2 and PI3. For the latter, the associated attributes were sweet aroma, honey aroma, honey taste, cooked fruit taste, sweet taste, pinkish red color and firm.

Previous CATA results show that this test reveals how products are evaluated and differentiated by the consumers, justifying the hedonic scale results in accepting or not accepting the products, e.g., MM3 and PI1 samples that have not been accepted by overall intent to consume were associated with favorable attributes such as: strange taste, strange texture, bitter taste, soft, presence of liquid and mango flavor baked in formulating MM3; and second: presence of liquid, dark red color, aroma, acid, sour taste, strange texture, soft, sour taste and opaque color. However, the sample $\mathrm{C} 1$ was well evaluated by the hedonic test and was associated with sweet taste, homogeneous and light yellow color.

\subsection{Microbiological test results}

All the formulations showed an absence of Salmonella in predefined times in this experiment.

The initial count $\left(\mathrm{T}_{0}\right)$ of psychotropic microorganisms in all the formulations were $<10 \mathrm{CFU} / \mathrm{g}$. From the $\mathrm{T}_{16}$, the formulations from the caja logarithmic cycle presented more $\left(10^{4} \mathrm{CFU} / \mathrm{g}\right)$
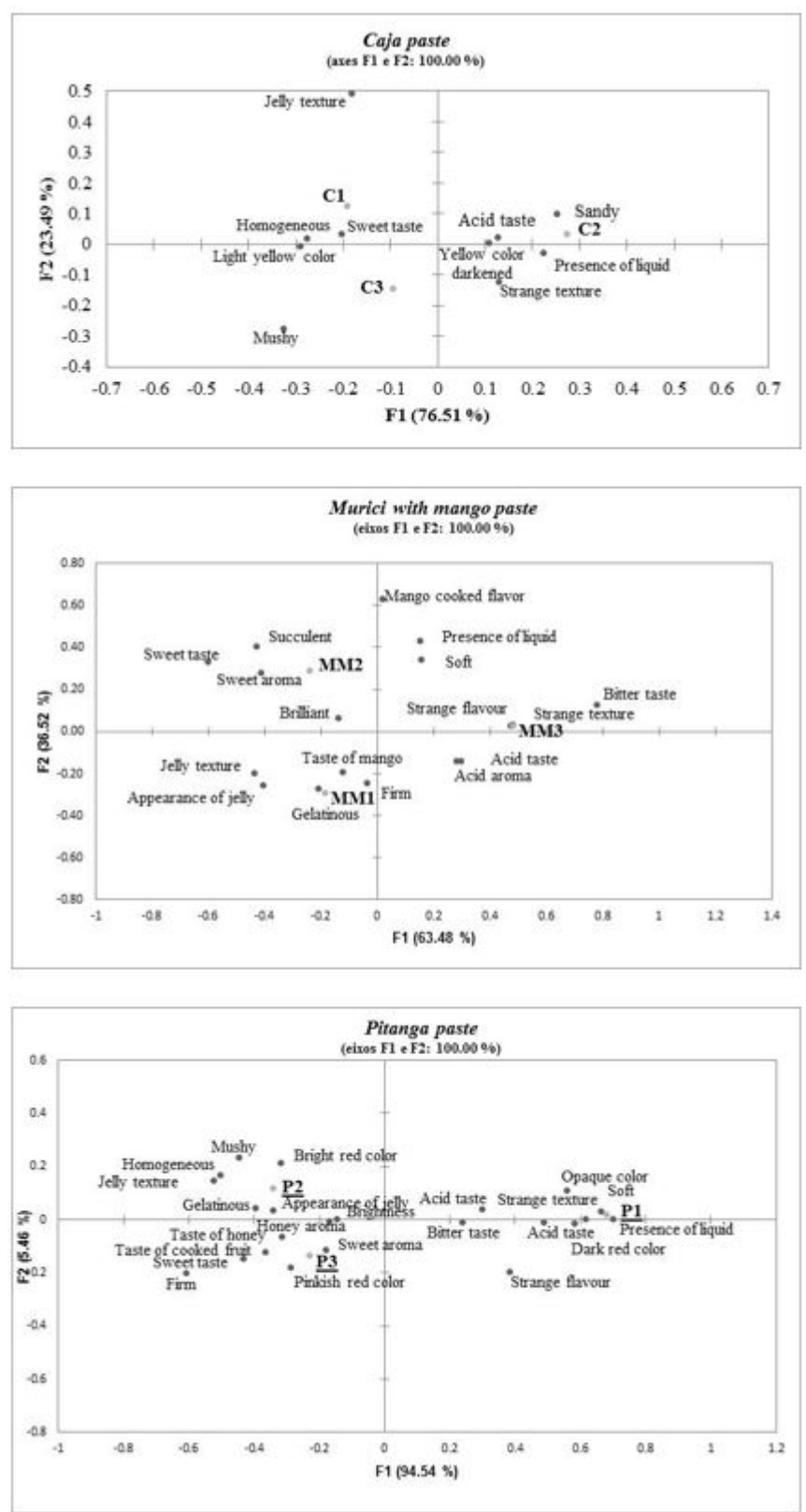

Figure 1. Principal Component Analysis (PCA) of the CATA test of the formulations of fruit pastes. C1 = caja pulp:honey $90: 10$ and Gellan gum $0.6 \%$; C2 = caja pulp:honey $86: 14$ and Gellan gum $0.6 \%$; C3 = caja pulp:honey $86: 14$ and Gellan gum 0.7\%; MM1 = murici pulp:mango pulp:honey 45:45:10 and Gellan gum 0.1\%; MM2 = murici pulp:mango pulp:honey 45:45:10 and Gellan gum 0.2\%; MM3 = murici pulp:mango pulp:honey 50:50:00 and Gellan gum 0.25\%; PI1 = pitanga pulp:honey 90:10 and Gellan gum 0.6\%; PI2 = pitanga pulp:honey 86:14 and Gellan gum 0.6\%; PI3 = pitanga pulp:honey 86:14 and Gellan gum 0.75\%. 
than in the formulations of pitanga and murici with mango $\left(10^{3} \mathrm{CFU} / \mathrm{g}\right.$, respectively).

On the data presented, the product is stable during the investigation, in terms of refrigeration $\left(4{ }^{\circ} \mathrm{C}\right)$. The brazilian sanitary prevailing legislation (Brasil, 2001) considers food safe for consumption when present microbiological counts less than $10^{5} \mathrm{CFU} / \mathrm{g}$, because $\geq 10^{6} \mathrm{CFU} / \mathrm{g}$ are considered contaminated and, in this range, the deterioration in some food start to become visible, in others it is necessary to count $\geq 10^{8} \mathrm{CFU} / \mathrm{g}$.

Similar to the results of this research were published by Grizotto et al. (2006) observed microbial growth (molds and yeasts) in structured dehydrated papaya during 120 days of observation.

Therefore, it can be affirmed that the microbiological stability of the developed fruit pastes may be associated with the high acidity of the fruit and hygienic sanitary conditions adopted during processing, as well as the quality of raw materials.

\section{Conclusions}

The developed fruit pastes (caja, pitanga and murici with mango) showed antioxidant activity (between 3.34 and $11.79 \mu \mathrm{M} /$ Trolox) and vitamin $C$ content (between 10.91 and $68.46 \mathrm{mg} / 100 \mathrm{~g}$ ), with accessibility to the human organism above $21 \%$ and $15 \%$ respectively. The pastes were sensorially accepted, except MM3 (murici pulp:mango pulp:honey 50:50:00) and PI1 (pitanga pulp:honey 90:10 and gellan gum $0.6 \%$ ) formulations as they received low average hedonics correlated with undesirable terms by CATA. Regarding the above, it can be concluded that fruit pastes are new structured products with a gellan gum, practical because they are ready and easy consumption. In addition, they are fruit-based products of agro-biodiversity in the Brazilian Northeast.

\section{Acknowledgements}

The authors thank the funding agencies Food and Agriculture Organization of United States, Programa das Nações Unidas para o Meio Ambiente (PNUMA), and Ministério do Meio Ambiente for the financial support received.

\section{References}

American Public Health Association - APHA. Committee on Microbiological for Foods. (2001). Compendium of methods for the microbiological examination of foods (4th ed.). Washington: APHA.

Araujo, R. R., Sandos, E. D., Lemos, E. E. P., \& Alves, R. E. (2009). Biometric characterization of fruits and seeds of genotypes of murici (Byrsonima verbascifolia (1.) Rich.) of coastal Board of Alagoas. Caatinga, 22(3), 224-228.

Ares, G., Etchemendy, E., Antúnez, L., Vidal, L., Giménez, A., \& Jaeger, S. R. (2014). Visual attention by consumers to check-all-that-apply questions: insights to support methodological development. Food Quality and Preference, 32, 210-220. http://dx.doi.org/10.1016/j. foodqual.2013.10.006.

Association of Official Analytical Chemists - AOAC. (2005). Official methods of analysis of the Association of Official Analytical Chemists (18th ed.). Gaithersburg: AOAC.
Bagetti, M., Facco, E. M. P., Piccolo, J., Hirsch, G. E., Rodriguez-Amaya, D., Kobori, C. N., Vizzotto, M., \& Emanuelli, T. (2011). Physicochemical characterization and antioxidant capacity of pitanga fruits (Eugenia uniflora L.). Food Science and Technology, 31(1), 147-154. http:// dx.doi.org/10.1590/S0101-20612011000100021.

Banerjee, S., Ravi, R., \& Bhattacharya, S. (2013). Textural characterisation of gellan and agar based fabricated gels with carrot juice. Food Science and Technology, 53(1), 255-261.

Brasil. Agência Nacional de Vigilância Sanitária. (2001, January 10). Aprova o Regulamento Técnico sobre padrões microbiológicos para alimentos (Resolução RDC n ${ }^{\circ} 12$, de 2 de janeiro de 2001). Diário Oficial [da] República Federativa do Brasil. Retrieved from http:// portal.anvisa.gov.br/documents/33880/2568070/RDC_12_2001. pdf/15ffddf6-3767-4527-bfac-740a0400829b

Briones-Labarca, V., Venegas-Cubillos, G., Ortiz-Portilla, S., ChacanaOjeda, M., \& Maureira, H. (2011). Effects of high hydrostatic pressure (HHP) on bioaccessibility, as well as antioxidant activity, mineral and starch contents in Granny Smith apple. Food Chemistry, 128(2), 520-529. http://dx.doi.org/10.1016/j.foodchem.2011.03.074. PMid:25212164.

Canuto, G. A. B., Xavier, A. A. O., Neves, L. C., \& Benassi, M. T. (2010). Physical-chemical characterisation of Amazonian fruit pulps and correlation with your free anti-radical activity. Brazilian Journal of Horticulture, 32(4), 1196-1205.

Carvalho, J. M., Maia, G. A., Fonseca, A. V. V., Sousa, P. H. M., \& Rodrigues, S. (2015). Effect of processing on physicochemical composition, bioactive compounds and enzymatic activity of yellow mombin (Spondias mombin L.) tropical juice. Journal of Food Science and Technology, 52(2), 1182-1187. PMid:25694737.

Castura, J. C., Antunez, L., Gimenez, A., \& Ares, G. (2016). Temporal Check-All-That-Apply (TCATA): a novel dynamic method for characterizing products. Food Quality and Preference, 47, 79-90. http://dx.doi.org/10.1016/j.foodqual.2015.06.017.

Costa, E. A., Brito, S. A., Sousa, P. H. M., Siqueira, A. C. P., Cunha, E. C. B., \& Nascimento, L. G. L. (2017). Estruturado de murici (Byrsonima crassifolia (L.) Kunth) a base de hidrocoloide: elaboração e caracterização físico-química. Arquivos Brasileiros de Alimentação, 2(3), 174-181.

Danalache, F., Beirão-da-Costa, S., Mata, P., Alves, V. D., \& MoldãoMartins, M. (2015a). Texture, microstructure and consumer preference of mango bars jellified with gellan gum. Lebensmittel-Wissenschaft + Technologie, 62(1), 584-591. http://dx.doi.org/10.1016/j.lwt.2014.12.040.

Danalache, F., Mata, P., Moldão-Martins, M., \& Alves, V. D. (2015b). Novel mango bars using gellan gum as gelling agent: rheological and microstructural studies. Food Science and Technology, 62, 576-583.

Dickinson, E. (2009). Hydrocolloids as emulsifiers and emulsion stabilizers. Food Hydrocolloids, 23(6), 1473-1482. http://dx.doi. org/10.1016/j.foodhyd.2008.08.005.

Dooley, L., Lee, Y., \& Meullenet, J. (2010). The application of Check-AllThat-Apply (CATA) consumer profiling to preference mapping of vanilla ice cream and its comparison to classical external preference mapping. Food Quality and Preference, 21(4), 394-401. http://dx.doi. org/10.1016/j.foodqual.2009.10.002.

Dutcosky, S. D. (2013). Análise sensorial de alimentos (4. ed.). Curitiba: Champagnat-PUCPRESS.

Gadelha, A. J. F., Rocha, C. da O., Vieira, F. F. \& Ribeiro, G. N. (2009). Evaluation of physico-chemical quality parameters of frozen pulp of pineapple, acerola, caja and cashews. Caatinga, 22(1), 115-118.

Grizotto, R. K., Berbari, S. A. G., Moura, S. C. S. R., \& Claus, M. L. (2006). Study of the shelf-life of structured and dehydrated fruit obtained 
from concentrated pulp of papaya. Food Science and Technology, 26(3), 709-714. http://dx.doi.org/10.1590/S0101-20612006000300035.

Lersch, M. (2014). Texture: a hydrocolloid recipe collection (1st ed., Vol. 3). San Francisco: Creative Commons.

Li, J. M., \& Nie, S. P. (2015). The functional and nutritional aspects of hydrocolloids in foods. Food Hydrocolloids, 53, 46-61. http://dx.doi. org/10.1016/j.foodhyd.2015.01.035.

Maia, G. A., Sousa, P. H. M., Lima, A. S., Carvalho, J. M., \& Figueiredo, R. W. (2009). Tropical fruit processing (1st ed.). Fortaleza: UFC.

Martins, N., Barros, L., \& Ferreira, I. C. F. R. (2016). In vivo antioxidant activity of phenolic compounds: facts and gaps. Trends in Food Science \& Technology, 48, 1-12. http://dx.doi.org/10.1016/j.tifs.2015.11.008.

Miller, D. D., Schricker, B. R., Rasmussen, R. R., \& Van Campen, D. (1981). In vitro method for estimation of iron availability from meals. The American Journal of Clinical Nutrition, 34(10), 22482256. http://dx.doi.org/10.1093/ajcn/34.10.2248. PMid:6794346.

Moura, N. C., \& Canniatti-Brazaca, S. G. (2006). Avaliação da disponibilidade de ferro de feijão comum (Phaseolus vulgaris L.) em comparação com a carne bovina. Food Science and Technology, 26(2), 270-276. http://dx.doi.org/10.1590/S0101-20612006000200007.

Phillips, G. O., \& Williams, P. A. (2009). Handbook of hydrocolloids (2nd ed.). USA: CRC Press. http://dx.doi.org/10.1533/9781845695873.

Plaehn, D. (2012). CATA penalty/reward. Food Quality and Preference, 24(1), 141-152. http://dx.doi.org/10.1016/j.foodqual.2011.10.008.

Re, R., Pellegrini, N., Proteggente, A., Pannala, A., Yang, M., \& RiceEvans, C. (1999). Antioxidant activity applying an improved ABTS radical cation decolorization assay. Free Radical Biology \& Medicine, 26(9-10), 1231-1237. http://dx.doi.org/10.1016/S0891-5849(98)003153. PMid:10381194.

Rocha, M. S., Figueiredo, R. W., Araújo, M. A. M., \& Moreira-Araújo, R. S. R. (2013). Physico-chemical characterization and antioxidant activity (in vitro) of fruits in the cerrado of Piauí. Brazilian Journal of Horticulture, 35(4), 933-941.

Rufino, M. S. M., Alves, R. E., Brito, E. S., Pérez-Jiménez, J., SauraCalixto, F., \& Mancini-Filho, J. (2010). Bioactive compounds and antioxidant capacities of 18 non-traditional tropical fruits from Brazil. Food Chemistry, 121(4), 996-1002. http://dx.doi.org/10.1016/j. foodchem.2010.01.037.

Silva, N., Junqueira, V. C. A., Silveira, N. F. A., Taniwaki, M. H., Santos, R. F. S., \& Gomes, R. A. R. (2010). Manual of methods of microbiological analysis of food and water (4th ed.). São Paulo: Bookstore Varela.

Souza, V. R., Pereira, P. A. P., Queiroz, F., Borges, S. V., \& Carneiro, J. D. (2012). Determination of bioactive compounds, antioxidant activity and chemical composition of Cerrado Brazilian fruits. Food Chemistry, 134(1), 381-386. http://dx.doi.org/10.1016/j.foodchem.2012.02.191.

Stone, H., \& Sidel, J. L. (2004). Sensory evaluation practices (3rd ed.). New York: Academic Press.

Universidade Estadual de Campinas - UNICAMP. Núcleo de Estudos e Pesquisas em Alimentação - NEPA. (2011). Tabela Brasileira de Composição de Alimentos: TACO (4. ed.). Campinas: UNICAMP.

XLSTAT. (2017). Statistical software \& data analysis add-on for Excel, versão 2.0 . 
Appendix A. Supplementary Material.

Table A1. Terms presented on the sensory test sheets Check-All-That-Apply questions (CATA) for the prepared fruit pastes.

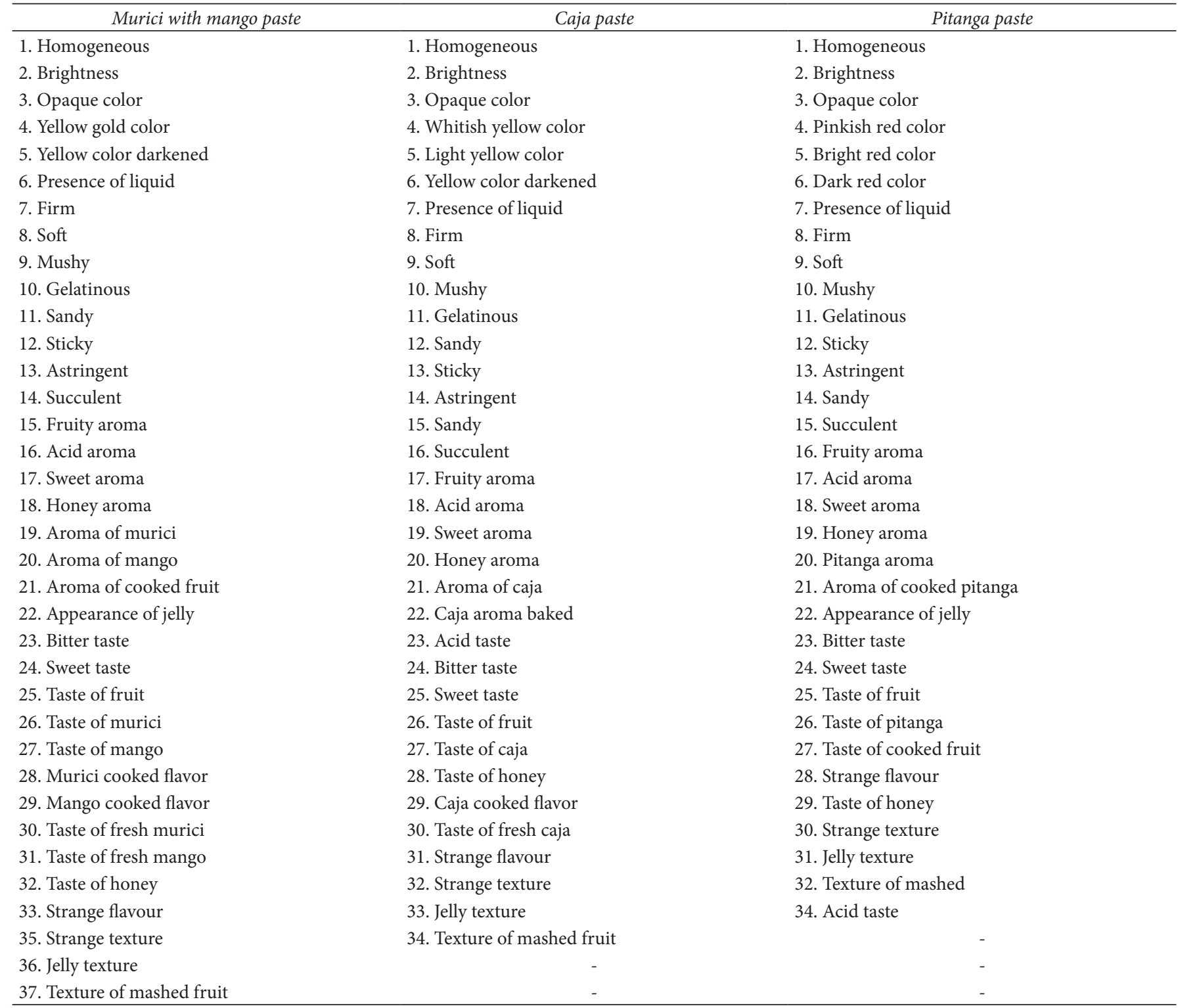


Table A2. Cochran Q test results of fruit paste formulations.

\begin{tabular}{|c|c|c|c|c|c|c|c|c|c|}
\hline \multirow{2}{*}{ Attributes / Samples } & \multicolumn{3}{|c|}{ Caja paste } & \multicolumn{3}{|c|}{ Pitanga paste } & \multicolumn{3}{|c|}{ Murici with mango paste } \\
\hline & $\mathrm{C} 1$ & $\mathrm{C} 2$ & $\mathrm{C} 3$ & PI1 & PI2 & PI3 & MM1 & MM2 & MM3 \\
\hline Homogeneous & $0.182(a)$ & $0.354(\mathrm{~b})$ & $0.323(\mathrm{ab})$ & 0.059 (a) & $0.446(\mathrm{c})$ & $0.277(b)$ & $0.198(\mathrm{a})$ & $0.188(\mathrm{a})$ & 0.129 (a) \\
\hline Brightness & $0.414(\mathrm{a})$ & $0.465(a)$ & $0.455(\mathrm{a})$ & $0.327(\mathrm{a})$ & 0.604 (b) & $0.554(\mathrm{~b})$ & $0.584(\mathrm{~b})$ & $0.644(\mathrm{~b})$ & $0.396(\mathrm{a})$ \\
\hline Opaque color & $0.212(a)$ & $0.121(\mathrm{a})$ & $0.182(\mathrm{a})$ & $0.198(b)$ & $0.089(\mathrm{ab})$ & $0.069(\mathrm{a})$ & $0.158(a)$ & $0.139(\mathrm{a})$ & $0.149(\mathrm{a})$ \\
\hline Whitish yellow color & $0.030(\mathrm{a})$ & $0.030(\mathrm{a})$ & $0.030(\mathrm{a})$ & n.a. & n.a. & n.a. & n.a. & n.a. & n.a. \\
\hline Yellow color darkened & n.a. ${ }^{1}$ & n.a. & n.a. & n.a. & n.a. & n.a. & $0.119(\mathrm{a})$ & $0.099(\mathrm{a})$ & $0.119(\mathrm{a})$ \\
\hline Yellow gold color & n.a. & n.a. & n.a. & n.a. & n.a. & n.a. & $0.426(\mathrm{a})$ & $0.525(a)$ & $0.446(\mathrm{a})$ \\
\hline Pinkish red color & n.a. & n.a. & n.a. & $0.079(\mathrm{a})$ & $0.188(b)$ & $0.238(b)$ & n.a. & n.a. & n.a. \\
\hline Bright red color & n.a. & n.a. & n.a. & $0.069(\mathrm{a})$ & $0.228(b)$ & $0.129(\mathrm{ab})$ & n.a. & n.a. & n.a. \\
\hline Dark red color & n.a. & n.a. & n.a. & $0.228(\mathrm{~b})$ & 0.079 (a) & $0.099(a)$ & n.a. & n.a. & n.a. \\
\hline Presence of liquid & $0.293(b)$ & $0.162(\mathrm{a})$ & $0.212(\mathrm{ab})$ & $0.505(b)$ & 0.139 (a) & $0.178(a)$ & $0.069(a)$ & $0.228(b)$ & $0.188(\mathrm{ab})$ \\
\hline Gelatinous & $0.061(a)$ & $0.091(\mathrm{a})$ & $0.051(\mathrm{a})$ & $0.109(\mathrm{a})$ & $0.446(b)$ & $0.356(b)$ & $0.594(b)$ & $0.317(\mathrm{a})$ & $0.228(\mathrm{a})$ \\
\hline Sandy & $0.202(b)$ & $0.121(\mathrm{ab})$ & $0.111(\mathrm{a})$ & $0.069(\mathrm{a})$ & $0.020(\mathrm{a})$ & $0.030(\mathrm{a})$ & $0.446(a)$ & $0.535(\mathrm{a})$ & $0.525(\mathrm{a})$ \\
\hline Sticky & $0.040(a)$ & $0.030(\mathrm{a})$ & $0.020(\mathrm{a})$ & $0.168(\mathrm{a})$ & $0.129(\mathrm{a})$ & $0.168(a)$ & $0.059(\mathrm{a})$ & $0.020(\mathrm{a})$ & $0.089(\mathrm{a})$ \\
\hline Astringent & $0.172(a)$ & $0.111(\mathrm{a})$ & $0.152(a)$ & $0.228(\mathrm{a})$ & $0168(a)$ & $0.149(\mathrm{a})$ & 0.149 (a) & $0.079(\mathrm{a})$ & $0.188(a)$ \\
\hline Succulent & 0.091 (a) & $0.131(\mathrm{a})$ & $0.152(\mathrm{a})$ & $0.079(\mathrm{a})$ & 0.109 (a) & $0.079(\mathrm{a})$ & $0.089(\mathrm{ab})$ & $0.198(b)$ & $0.040(\mathrm{a})$ \\
\hline Fruity aroma & $0.374(\mathrm{a})$ & $0.293(\mathrm{a})$ & $0.364(\mathrm{a})$ & $0.238(\mathrm{a})$ & 0.317 (a) & $0.277(\mathrm{a})$ & $0.287(a)$ & $0.287(\mathrm{a})$ & $0.168(\mathrm{a})$ \\
\hline Acid aroma & $0.323(\mathrm{a})$ & $0.222(\mathrm{a})$ & $0.253(\mathrm{a})$ & $0.436(b)$ & $0.188(a)$ & $0.218(\mathrm{a})$ & $0.277(\mathrm{ab})$ & $0.158(a)$ & 0.337 (b) \\
\hline Sweet aroma & $0.081(\mathrm{a})$ & $0.162(\mathrm{a})$ & $0.162(\mathrm{a})$ & 0119 (a) & $0.208(\mathrm{a})$ & $0.238(\mathrm{a})$ & $0.129(\mathrm{ab})$ & $0.218(b)$ & $0.050(\mathrm{a})$ \\
\hline Honey aroma & $0.182(a)$ & $0.222(\mathrm{a})$ & $0.182(\mathrm{a})$ & 0.119 (a) & $0.208(a)$ & $0.188(a)$ & $0.050(\mathrm{a})$ & $0.089(\mathrm{a})$ & $0.050(\mathrm{a})$ \\
\hline Pitanga aroma & & & & $0.287(\mathrm{a})$ & $0.228(a)$ & 0267 (a) & n.a. & n.a. & n.a. \\
\hline Aroma of murici & n.a. & n.a. & n.a. & n.a. & n.a. & n.a. & $0.455(\mathrm{a})$ & $0.386(a)$ & $0.356(\mathrm{a})$ \\
\hline Sweet taste & $0.202(a)$ & $0.323(\mathrm{a})$ & $0.293(\mathrm{a})$ & $0.050(\mathrm{a})$ & $0.228(b)$ & $0.257(b)$ & $0.168(b)$ & 0.307 (b) & $0.020(\mathrm{a})$ \\
\hline Fruit taste & $0.192(a)$ & $0.222(\mathrm{a})$ & $0.253(\mathrm{a})$ & $0.168(a)$ & $0.208(a)$ & $0.198(a)$ & 0.257 (a) & $0.337(\mathrm{a})$ & $0.218(\mathrm{a})$ \\
\hline Taste of murici & n.a. & n.a. & n.a. & n.a. & n.a. & n.a. & 0.495 (a) & 0.485 (a) & $0.465(\mathrm{a})$ \\
\hline Taste of pitanga & n.a. & n.a. & n.a. & 0.287 (a) & 0.277 (a) & 0.337 (a) & n.a. & n.a. & n.a. \\
\hline Taste of mango & n.a. & n.a. & n.a. & n.a. & n.a. & n.a. & 0.307 (a) & $0.188(a)$ & $0.158(a)$ \\
\hline Caja taste & 0.667 (a) & $0.606(a)$ & $0.707(\mathrm{a})$ & $0.030(a)$ & 0.099 (a) & 0.109 (a) & n.a. & n.a. & n.a. \\
\hline Taste of honey & $0.212(\mathrm{a})$ & $0.283(\mathrm{a})$ & $0.263(\mathrm{a})$ & $0.050(\mathrm{a})$ & $0.139(b)$ & $0.139(\mathrm{~b})$ & $0.030(\mathrm{a})$ & $0.079(\mathrm{a})$ & $0.030(\mathrm{a})$ \\
\hline Cooked Caja flavor & $0.141(a)$ & $0.091(\mathrm{a})$ & $0.172(\mathrm{a})$ & n.a. & n.a. & n.a. & n.a. & n.a. & n.a. \\
\hline Cooked Murici flavor & n.a. & n.a. & n.a. & n.a. & n.a. & n.a. & $0.129(a)$ & $0.129(\mathrm{a})$ & $0.158(a)$ \\
\hline Cooked mango flavor & n.a. & n.a. & n.a. & n.a. & n.a. & n.a. & $0.020(\mathrm{a})$ & $0.139(b)$ & $0.079(\mathrm{ab})$ \\
\hline Taste of Caja fresh & $0.081(a)$ & $0.081(\mathrm{a})$ & $0.071(\mathrm{a})$ & n.a. & n.a. & n.a. & n.a. & n.a. & n.a. \\
\hline Taste of fresh murici & n.a. & n.a. & n.a. & n.a. & n.a. & n.a. & 0.099 (a) & $0.050(\mathrm{a})$ & $0.030(\mathrm{a})$ \\
\hline Taste of fresh mango & n.a. & n.a. & n.a. & n.a. & n.a. & n.a. & $0.020(a)$ & $0.040(\mathrm{a})$ & $0(a)$ \\
\hline Strange flavor & $0.061(\mathrm{a})$ & $0.061(\mathrm{a})$ & $0.020(\mathrm{a})$ & $0.178(\mathrm{a})$ & $0.069(\mathrm{a})$ & $0.139(\mathrm{a})$ & 0.139 (a) & $0.129(\mathrm{a})$ & $0.297(b)$ \\
\hline Strange texture & $0.313(\mathrm{a})$ & $0.192(\mathrm{a})$ & $0.303(\mathrm{a})$ & $0.297(b)$ & $0.099(\mathrm{a})$ & $0.119(\mathrm{a})$ & $0.218(\mathrm{a})$ & $0.198(a)$ & $0.455(b)$ \\
\hline Jelly texture & $0.061(a)$ & $0.111(\mathrm{a})$ & $0.030(\mathrm{a})$ & $0.050(\mathrm{a})$ & $0.426(b)$ & $0.277(b)$ & $0.218(b)$ & $0.149(\mathrm{ab})$ & $0.040(\mathrm{a})$ \\
\hline Texture of mashed fruit & $0.253(\mathrm{a})$ & $0.263(\mathrm{a})$ & $0.182(a)$ & $0.119(a)$ & 0.109 (a) & 0.109 (a) & $0.208(a)$ & $0.168(a)$ & $0.109(a)$ \\
\hline
\end{tabular}




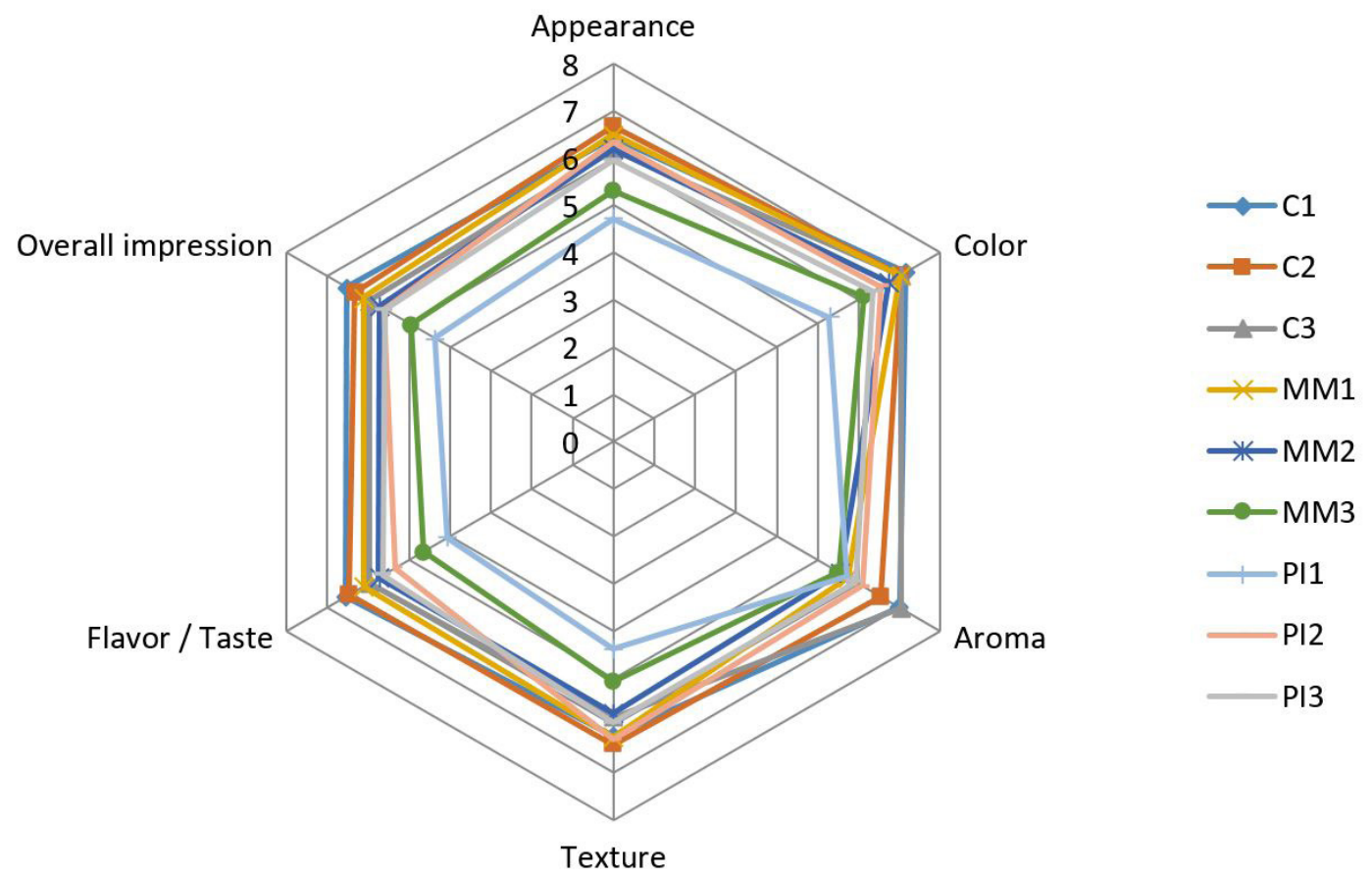

Figure A1. Sensory profile of the fruit paste formulations. C1: caja pulp:honey 90:10 and Gellan gum 0.6\%; C2: caja pulp:honey 86:14 and Gellan gum $0.6 \%$; C3: caja pulp:honey 86:14 and Gellan gum 0.7\%; MM1: murici pulp:mango pulp:honey 45:45:10 and Gellan gum 0.1\%; MM2: murici pulp:mango pulp:honey 45:45:10 and Gellan gum 0.12\%; MM3: murici pulp:mango pulp:honey 50:50:00 and Gellan gum 0.25\%; PI1: pitanga pulp:honey 90:10 and Gellan gum 0.6\%; PI2: pitanga pulp:honey 86:14 and Gellan gum 0.6\%; PI3: pitanga pulp:honey 86:14 and Gellan gum 0.75\%. 